Original Article

\title{
FORMULATION OPTIMIZATION AND EVALUATION OF MOUTH DISSOLVING FILM OF RAMOSETRON HYDROCHLORIDE
}

\author{
ZANKAHANA PATEL, RAHIL BHURA, SAMIR SHAH \\ Department of Pharmaceutics, Sardar Patel College of Pharmacy, Bakrol, 388315, Gujarat, India \\ Email: rahilbhura@gmail.com
}

Received: 22 Jan 2020, Revised and Accepted: 19 Mar 2020

\begin{abstract}
Objective: Ramosetron Hydrochloride is found to be more potent and having a longer duration of action with the least side effects, but the major drawback is it undergoes hepatic first-pass metabolism so our aim is to prepare mouth dissolving film (MDF) of Ramosetron hydrochloride for rapid relief in emesis.

Methods: The mouth dissolving films of Ramosetron Hydrochloride were prepared by using the solvent casting method. Films were formulated using HPMC E5 (Hydroxy Propyl Methyl Cellulose) as a film-forming agent, PEG400 (Polyethylene glycol) as a plasticizer and Aspartame as the sweetening agent. A $3^{2}$ full factorial design was applied considering the concentration of HPMC E5 $\left(\mathrm{X}_{1}\right)$ and concentration of PEG400 $\left(\mathrm{X}_{2}\right)$ as independent variables and \% cumulative drug release $\left(\mathrm{Y}_{1}\right)(\mathrm{CDR})$, disintegration time $\left(\mathrm{Y}_{2}\right)(\mathrm{DT})$ and tensile strength $\left(\mathrm{Y}_{3}\right)(\mathrm{TS})$ as dependent variables. The prepared films were evaluated for thickness, folding endurance, tensile strength, disintegration time, drug content uniformity and taste masking by E-tongue. The results indicated that factors $\mathrm{X}_{1}$ and $\mathrm{X}_{2}$ were found to be having a positive effect on DT and TS and negative effects on CDR.
\end{abstract}

Results: The optimized formulation was found to be the best with $94.00 \pm 0.85 \%$ in vitro drug release, $33.22 \pm 0.75 \mathrm{sec}$ DT and $1.359 \pm 0.005 \mathrm{~g} / \mathrm{mm}^{2}$ tensile strength. Concentration of aspartame was optimized with E-tongue taking into consideration increased electric potential with decreasing bitterness.

Conclusion: Thus, a rapidly dissolving oral film of Ramosetron Hydrochloride with successful taste masking and immediate in vitro drug release was prepared using a solvent casting technique.

Keywords: Ramosetron Hydrochloride, Rapidly dissolving oral film, E-tongue, HPMC E5

(C) 2020 The Authors. Published by Innovare Academic Sciences Pvt Ltd. This is an open access article under the CC BY license (http://creativecommons.org/licenses/by/4.0/] DOI: http://dx.doi.org/10.22159/ijcpr.2020v12i3.38315. Journal homepage: https://innovareacademics.in/journals/index.php/ijcpr

\section{INTRODUCTION}

Amongst the different routes, the most agreeable route for the patients is an oral route. But some patients, particularly pediatrics and geriatrics have complications in swallowing or chewing certain oral solid dosage forms like tablets and hard gelatin capsules [1]. Mouth dissolving film (MDF) are a most advanced form of solid dosage form due to various reasons like flexibility, enhanced effectiveness of active pharmaceutical ingredient, dissolution and disintegration within a minute with the help of less amount of saliva as compared to dissolving tablet [2]

Ramosetron Hydrochlorideis a white crystalline powder soluble in water and methanol. Ramosetron is a 5-HT3 receptor antagonist. It exerts its antiemetic property by blocking of serotonin to 5-HT3 receptors present in the afferent vagal nerve-endings in the GI mucosa. Ramosetron hydrochloride is a new selective 5 hydroxytryptamine type 3 (5-HT3) receptor antagonists that reportedly has more potent antiemetic effects compared with other 5-HT3 receptor antagonists [3]. It undergoes hepatic first-pass metabolism. It is found to be more potent and various studies have shown that it is having longer duration of actionand least unwanted side effects when compared to other antiemetics [4]. Its conventional tablets are available in the market but the major drawback of that is, tablet does not show the faster onset of action, which is required in case of emesis. Emesis is one of the side effect of cancer treatment and may happens with pregnant women hence our aim is to prepare rapidly dissolving film of Ramosetron hydrochloride for rapid relief in emesis.

\section{MATERIALS AND METHODS}

Materials s

Ramosetron Hydrochloride was a gratis sample from Cadila Healthcare Kundam, Goa. HPMC E3, HPMC E5, HPMC E15 (Chemdyes), PEG 400, Propylene Glycol, Glycerol (Krishna-Chem Industry), Aspartame (Chemdyes), Methanol (Chemdyes), Ethanol (Chemdyes). All chemicals and reagents used were of AR grade.
Drug polymer compatibility study

Fourier transform infrared spectroscopy (FTIR)

Compatibility studies were performed using the FT-IR spectrophotometer. The IR spectrum of the physical mixture of drug and polymer was studied by making a $\mathrm{KBr}$ disc and it was compared with the spectrum of pure drug. The peak in the spectra of physical mixture correlates with the peaks of the drug spectrum. This indicates the drug is compatible with the formulation component.

Differential scanning calorimetric (DSC)

The samples (2-4 mg) were heated in hermetically sealed flat-bottomed aluminum pans under nitrogen flow $(20 \mathrm{ml} / \mathrm{min})$ at a scanning rate of 10 ${ }^{\circ} \mathrm{C} /$ min from $25{ }^{\circ} \mathrm{C}$ to $200{ }^{\circ} \mathrm{C}$. Empty aluminum pan was used as the reference standard. The instrument was calibrated with the reference standard and scanned over a melting point range.

\section{Preparation of film}

Mouth dissolving film of Ramosetron Hydrochloride was prepared by the solvent casting method. The aqueous solution was prepared by dissolving the water-soluble polymer in water. The other ingredients were dissolved in Ethanol 95\% solution. Both mixtures were mixed to form homogenous viscous solution. The entrapped air was removed by putting it into sonicator. The resulting solution was casted as a film on a petridish and was allowed to dry. Prepared films were carefully removed from the petridish, checked for any imperfections and then cut into the $2 \times 2 \mathrm{~cm} 2$, each containing $5 \mathrm{mg}$ Ramosetron Hydrochloride. The films were stored in airtight plastic container till further use.

\section{Preliminary trials}

Optimization of film former and plasticizer

The placebo films were prepared using different polymer like HPMC E3, HPMC E5, HPMC E15 and plasticizer in range of 10 to $20 \% \mathrm{w} / \mathrm{v}$ by the solvent-casting method. Selection of polymer was done on the 
basis of appearance, folding endurance, film disintegration time and stickiness. Composition of preliminary batches are shown in table 1.

\section{Optimization of sweetener [5, 6]}

Optimization of sweetener was carried out by using different concentration of aspartame and mint flavor. The mouth dissolving films were dissolved in $50 \mathrm{ml}$ of distilled water. The reference electrode, working electrode and counter electrode (sensor array) were dipped in to beaker containing test solution. Potentiometric difference between each individually coated sensor with the $\mathrm{Ag} / \mathrm{AgCl}$ reference electrode was measured and recorded by the e-tongue software. Each sample was analyzed for $20 \mathrm{sec}$. The sensor array and reference electrode were then rinsed with distilled water. Using wellconditioned sensor, each sample was usually tested five times by the rotation procedure. The composition of batches is shown in table 2 .

\section{Experimental design [7]}

In order to investigate the effect of formulation variables on the responses, and to predict an optimized formulation, a $3^{2}$ factorial design was adopted. Nine batches were prepared as per the design layout shown in table 3 . In the present work, a $3^{2}$ full factorial design was adopted to find out the optimum combination of independent variables, the concentration of HPMC E5 $\left(\mathrm{X}_{1}\right)$ and PEG-400 $\left(\mathrm{X}_{2}\right)$ to obtain desired values of \% Cumulative Drug Release $\left(\mathrm{Y}_{1}\right)$, Disintegration Time $\left(\mathrm{Y}_{2}\right)$ and Tensile Strength $\left(\mathrm{Y}_{3}\right)$. Optimization study was performed using Design-Expert software (version 10). Polynomial models, including interaction terms, were generated for all the three responses. The statistical validity of the mathematical models was established on the basis of Analysis of Variance (ANOVA).

\section{Evaluation parameter}

\section{Tensile strength [8]}

Tensile strength is the maximum stress applied to a point at which the strip specimen breaks. It was calculated by the applied load at rupture divided by the cross-sectional area of the strip as given in the equation below:

$$
\text { Tensile strength }=\frac{\text { Load at failure } \times 100}{\text { Strip thickness } \times \text { Strip width }}
$$

\section{Folding endurance [9]}

Folding endurance was determined by repeated folding of the strip at the same place till the strip breaks. The number of times the film is folded without breaking was computed as the folding endurance value

\section{Weight variation}

For weight variation films were weighed individually on digital balance, then the average weight will be calculated.

\section{Thickness measurement [10]}

The thickness of the film $\left(2 \times 2 \mathrm{~cm}^{2}\right)$ was measured by micrometer screw gauge at three different places; averages of three values can be calculated.

\section{In vitro disintegration time [10]}

Disintegration time was visually determined by dipping the film $\left(2 \times 2 \mathrm{~cm}^{2}\right)$ in $25 \mathrm{ml}$ water in a beaker. The beaker was shaken gently and the time when the film starts to breaks or disintegrates was recorded.

\section{In vitro dissolution studies [10]}

In vitro dissolution time was performed using the USP basket type apparatus. The dissolution studies were carried out at $37 \pm 0.5^{\circ} \mathrm{C}$; with a stirring speed of $50 \mathrm{rpm}$ in $300 \mathrm{ml}$ phosphate buffer pH 6.8 . Five $\mathrm{ml}$ aliquots of dissolution media were collected at predetermined time intervals of $0,0.3,1,1.3,2,2.3,3,3.4,4,4.4,5,5.5,6$ min and replaced with the equal volume of fresh dissolution medium. The collected samples were filtered and the drug release was analyzed spectrophotometrically at $249 \mathrm{~nm}$ using UV-Visible spectrophotometer.

\section{Drug content}

Fast dissolving film of size $\left(2 \times 2 \mathrm{~cm}^{2}\right)$ was cut into small pieces and transferred into a graduated glass stoppered flask containing about $100 \mathrm{ml}$ of $6.8 \mathrm{pH}$ phosphate buffer. This solution was shaken properly till complete drug dissolves. It was filtered and the amount of drug present was determined after appropriate dilution using a UV-Visible spectrophotometer.

\section{Stability studies [10]}

The selected formulation was packed and sealed in aluminum packaging coated inside with polyethylene, they were then stored at $40{ }^{\circ} \mathrm{C}$ and $75 \%$ Relative Humidity (RH) for $1 \mathrm{mo}$ and evaluated for their physical appearance, drug content, disintegration time, and In vitro \% drug release at specified intervals of time and results were reported.

\section{RESULTS AND DISCUSSION}

\section{Drug polymer compatibility study}

\section{Fourier transform infrared spectroscopy (FTIR)}

Compatibility studies were performed using FT-IR spectrophotometer. FTIR spectra of drug and physical mixture is shown in fig. 1a and b. The peak in the spectra of physical mixture correlates with the peaks of the drug spectrum. This indicates the drug is compatible with the formulation component. Also, all the characteristics peaks of drug remain intact in the physical mixture.

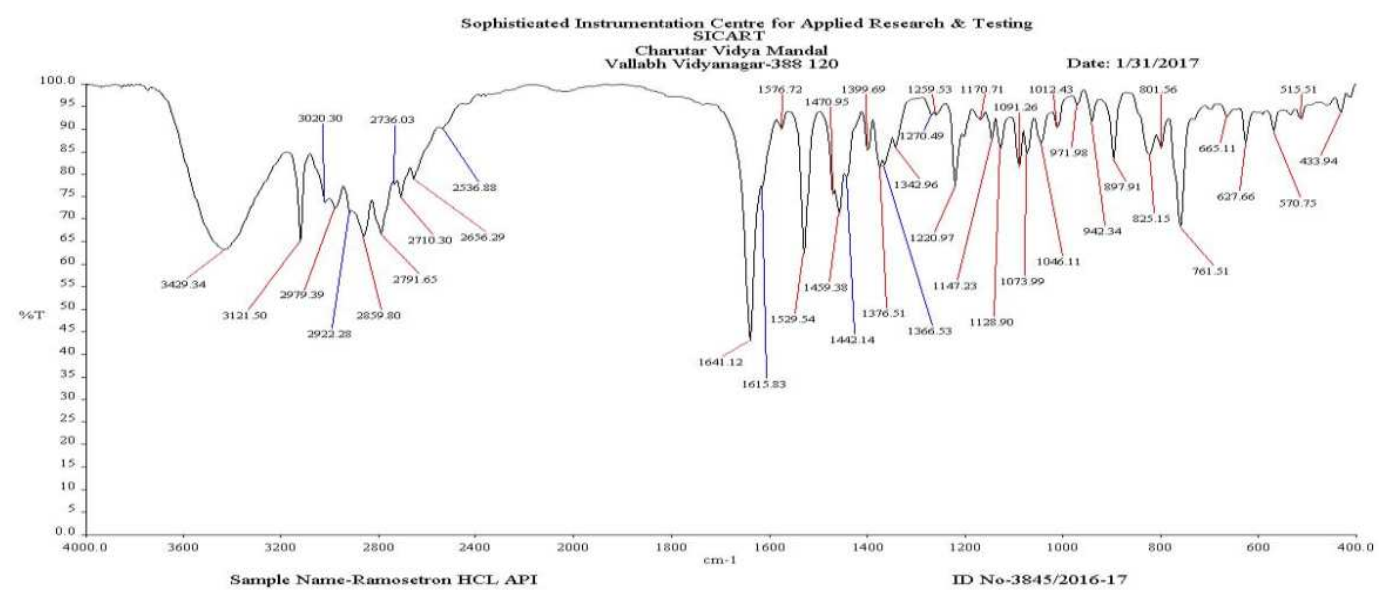

Fig. 1a: FTIR spectra of ramosetron hydrochloride 


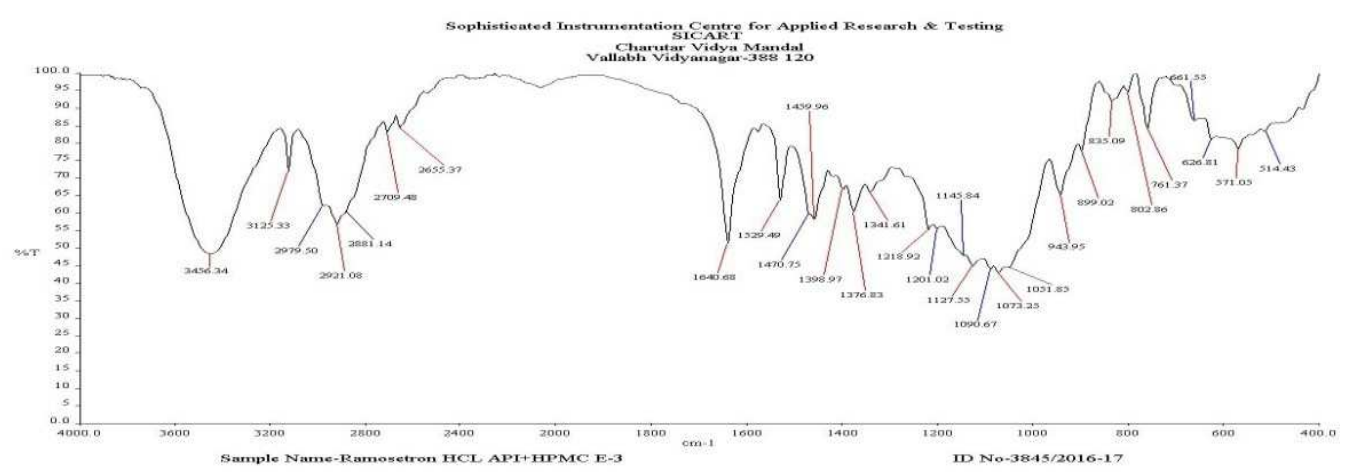

Fig. 1b: FTIR of ramosetron hydrochloride+HPMCE5 polymer

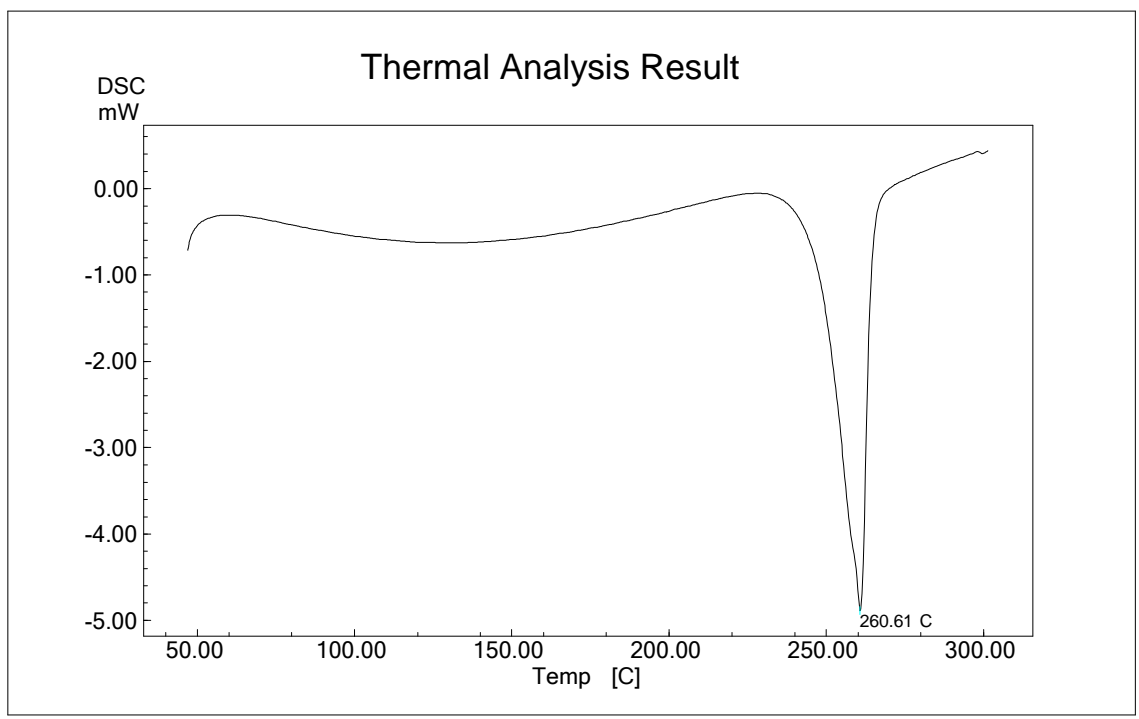

Fig. 2: DSC thermogram of ramosetron hydrochloride

\section{Differential scanning calorimetric (DSC)}

Ramosetron Hydrochloride showed sharp endothermic peak at $260.61{ }^{\circ} \mathrm{C}$ that corresponds to its melting range as shown in fig. 2 .

\section{Preliminary screening studies}

Preliminary studies were carried out to optimize the suitable film former polymer, plasticizer and concentration of sweetener, which is capable of producing film of desirable mechanical property and dissolution characteristics.

\section{Optimization of film former and plasticizer}

The films formed using HPMC E3 and E15 as a film former and Propylene glycol and Glycerol as plasticizer lacked suitable strength, were fragile having less folding endurance. However, the films with HPMC E5 and PEG 400 (B5) were found to be good in appearance with an acceptable physical characteristic. The films were easy to separate from petridish due to its non-sticky nature. It possessed good folding endurance and disintegration time within a minute. Films prepared using different film former and plasticizer is shown in fig. 3. Composition of preliminary batches and its results are shown in table 1.

Table 1: Preliminary screening MDF batches

\begin{tabular}{|c|c|c|c|c|c|c|c|c|}
\hline Batch & $\begin{array}{l}\text { Film forming } \\
\text { polymer }\end{array}$ & Plasticizer & $\begin{array}{l}\text { Film former conc. } \\
(\% \mathrm{w} / \mathrm{v})\end{array}$ & $\begin{array}{l}\text { Plasticize conc. } \\
(\% \mathrm{w} / \mathrm{v})\end{array}$ & Appearance & $\begin{array}{l}\text { Folding } \\
\text { endurance }\end{array}$ & $\begin{array}{l}\text { DT } \\
\text { (sec) }\end{array}$ & Stickiness \\
\hline 1. & HPMC E3 & $\begin{array}{l}\text { Propylene } \\
\text { Glycol }\end{array}$ & 3 & 10 & Good & 78 & 55 & $\begin{array}{l}\text { Slightly } \\
\text { Sticky }\end{array}$ \\
\hline 2. & & $\begin{array}{l}\text { Propylene } \\
\text { Glycol }\end{array}$ & 5 & 15 & Good & 95 & 61 & Sticky \\
\hline 3. & & $\begin{array}{l}\text { Propylene } \\
\text { Glycol }\end{array}$ & 7 & 20 & Good & 80 & 70 & Sticky \\
\hline 4. & HPMC E5 & PEG 400 & 3 & 10 & Good & 89 & 47 & Not Sticky \\
\hline 5. & & PEG 400 & 5 & 15 & Very Good & 102 & 54 & Not Sticky \\
\hline 6. & & PEG 400 & 7 & 20 & Good & 99 & 68 & Not Sticky \\
\hline 7. & HPMC E15 & Glycerol & 3 & 10 & Good & 75 & 53 & $\begin{array}{l}\text { Slightly } \\
\text { Sticky }\end{array}$ \\
\hline 8. & & Glycerol & 5 & 15 & Good & 92 & 59 & Sticky \\
\hline 9. & & Glycerol & 7 & 20 & Good & 89 & 75 & Very Sticky \\
\hline
\end{tabular}



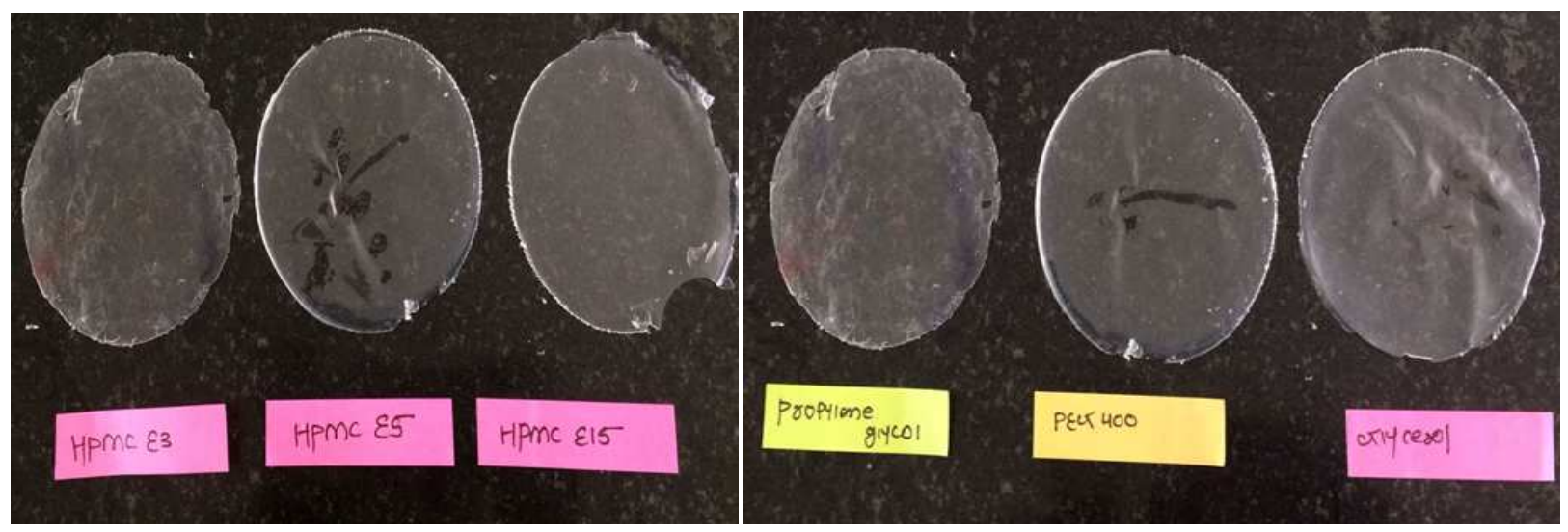

Fig. 3: Films prepared using different film former and plasticizer

Table 2: Batch composition for screening of aspartame concentration

\begin{tabular}{|c|c|c|c|c|}
\hline Ingredient & F1 & F2 & F3 & F4 \\
\hline Ramosetron hydrochloride (mg) & 73.075 & 73.075 & 73.075 & 73.075 \\
\hline HPMC E5 (mg) & 500 & 500 & 500 & 500 \\
\hline PEG $400(\%)$ & 15 & 15 & 15 & 15 \\
\hline Aspartame (mg) & 10 & 20 & 30 & 40 \\
\hline Menthol (mg) & 40 & 40 & 40 & 40 \\
\hline Ethanol (ml) & 7 & 7 & 7 & 7 \\
\hline Distilled Water (ml) & 5 & 5 & 5 & 5 \\
\hline
\end{tabular}

\section{Optimization of sweetener}

To mask the bitter taste of formulations, sweetener and flavor were incorporated. Aspartame was added as a sweetener in a different concentration ( 10 to $40 \mathrm{mg}$ ) and the mint flavor was added to fulfill the need of flavor. The prepared batches were evaluated for taste masking using E-tongue. The composition of batches is shown in table 2.

The effect of a sweetener, aspartame, on masking Ramosetron Hydrochloride bitterness was evaluated by e-Tongue and a Principal Component Analysis (PCA) map (fig. 4) was configured to determine the system discrimination power between the samples using the data generated. E-Tongue works on the principle that as the bitterness decreases, the electric potential increases. From the PCA map generated, it can be seen that F4 formulation showed the highest electric potential, hence minimum bitterness value thus sufficiently masking the bitter taste of the drug. F4 was considered as an optimized concentration of sweetener.

\section{Experimental design}

$3^{2}$ Factorial designs have often been applied to optimize the formulation variables with basic requirement of understanding the interaction of independent variables. Preliminary investigations of the process parameters revealed that factors like the concentration of HPMC E5 $\left(\mathrm{X}_{1}\right)$ and concentration of Plasticizer PEG 400( $\left.\mathrm{X}_{2}\right)$ showed significant influence on \% Cumulative drug release (\% CDR) $\left(Y_{1}\right)$, Disintegration time $\left(Y_{2}\right)$ and Tensile strength $\left(Y_{3}\right)$ of drugloaded mouth dissolving film. Hence, they were utilized for further systematic studies. Composition of the nine batches and its results are shown in table $3 a$.

Table 3a: $3^{2}$ Factorial design batches

\begin{tabular}{|c|c|c|c|c|c|}
\hline \multirow[t]{2}{*}{ Batch code } & \multicolumn{2}{|c|}{ Independent variables } & \multicolumn{3}{|l|}{ Dependent variable } \\
\hline & $\mathbf{X}_{1}$ & $\mathbf{X}_{2}$ & $\%$ Cumulative drug release $(\%)$ & Disintegration time (sec) & $\begin{array}{l}\text { Tensile strength } \\
\left(\mathrm{g} / \mathrm{mm}^{2}\right)\end{array}$ \\
\hline F1 & -1 & -1 & $98.05 \pm 0.4$ & $31.04 \pm 0.81$ & $0.835 \pm 0.003$ \\
\hline F2 & -1 & 0 & $97.43 \pm 0.7$ & $33.83 \pm 0.53$ & $0.862 \pm 0.003$ \\
\hline F3 & -1 & +1 & $97.03 \pm 0.8$ & $36.28 \pm 0.65$ & $0.882 \pm 0.003$ \\
\hline F4 & 0 & -1 & $96.18 \pm 0.6$ & $36.90 \pm 0.68$ & $1.531 \pm 0.008$ \\
\hline F5 & 0 & 0 & $95.48 \pm 0.5$ & $38.20 \pm 0.91$ & $1.562 \pm 0.009$ \\
\hline F6 & 0 & +1 & $94.85 \pm 0.7$ & $42.93 \pm 0.18$ & $1.678 \pm 0.007$ \\
\hline F7 & +1 & -1 & $90.81 \pm 0.7$ & $62.23 \pm 0.63$ & $1.893 \pm 0.04$ \\
\hline F8 & +1 & 0 & $89.26 \pm 0.8$ & $71.08 \pm 1.95$ & $2.132 \pm 0.006$ \\
\hline F9 & +1 & +1 & $86.77 \pm 0.6$ & $77.12 \pm 0.85$ & $2.283 \pm 0.01$ \\
\hline \multicolumn{2}{|c|}{ Independent variables } & $\operatorname{Low}(-1)$ & & High (+1) & \\
\hline \multicolumn{2}{|c|}{$\mathrm{X}_{1}$-HPMC E5 } & $3 \%$ & & $7 \%$ & \\
\hline \multicolumn{2}{|l|}{$\mathrm{X}_{2}$-PEG 400} & $10 \%$ & & $20 \%$ & \\
\hline
\end{tabular}

Mathematical relationships, generated using multiple linear regression analysis, gives an insight into the effect of independent variables on the dependent variables. A positive sign of coefficient indicates a synergistic effect, while a negative sign indicates an antagonistic effect upon the response. For estimation of the significance of the model, ANOVA was performed as per the provision of a Design Expert using 5 $\%$ significance level. A model is considered as significant if $\mathrm{p}<0.05$. ANOVA analysis is shown in table $3 \mathrm{~b}$. 


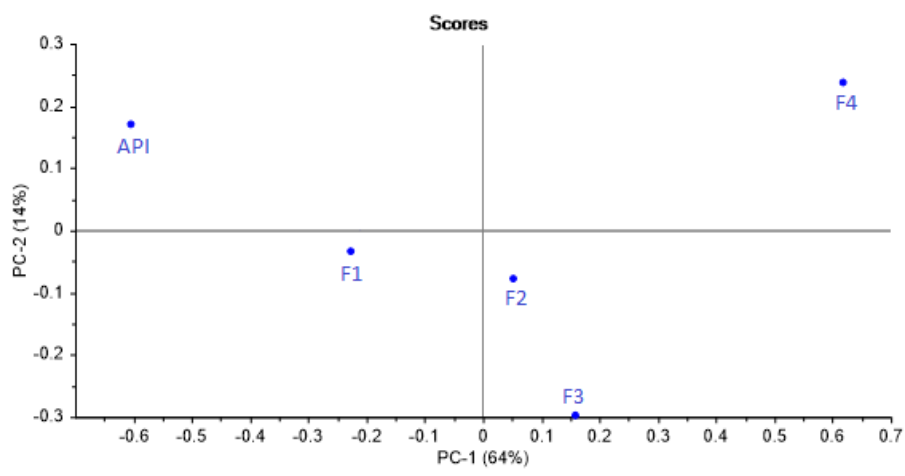

Fig. 4: PCA map of ramosetron hydrochloride in the presence of a different concentration of aspartame

Table 3b: ANOVA Analysis for the $3^{2}$ experimental design

\begin{tabular}{|c|c|c|c|c|c|c|}
\hline \multirow[t]{2}{*}{ Source } & \multicolumn{2}{|c|}{$Y_{1} \%$ cumulative drug release $(\%)$} & \multicolumn{2}{|c|}{$Y_{2}$ disintegration time (sec) } & \multicolumn{2}{|c|}{$\mathrm{Y}_{3}$ tensile strength $\left(\mathrm{g} / \mathrm{mm}^{2}\right)$} \\
\hline & F value & P value & F value & P value & F value & P-value \\
\hline $\mathrm{X}_{1}$ & 130.62 & 0.0010 & 50.75 & 0.0042 & 123.79 & $<0.0001$ \\
\hline $\mathrm{X}_{2}$ & 551.11 & 0.0002 & 202.30 & 0.0008 & 241.65 & $<0.0001$ \\
\hline $\mathrm{X}_{12}$ & 11.43 & 0.0431 & 2.80 & 0.1928 & & \\
\hline $\mathrm{X}_{1}^{2}$ & 57.76 & 0.0047 & 32.08 & 0.0109 & & \\
\hline $\mathrm{X}_{2}{ }^{2}$ & 0.50 & 0.5276 & 2.83 & 0.1910 & & \\
\hline PRESS & 7.25 & & 303.10 & & 0.16 & \\
\hline R square & 0.9954 & & 0.9883 & & 0.9763 & \\
\hline Adjusted R Square & 0.9878 & & 0.9688 & & 0.9685 & \\
\hline Predicted R Square & 0.9448 & & 0.8579 & & 0.9345 & \\
\hline
\end{tabular}

The statistically insignificant terms $(p>0.05)$ were omitted to generate the reduced model. Reduced model for each response are shown below:

$\%$ Cumulative drug release $(\% \mathrm{CDR})\left(\mathrm{Y}_{1}\right)=+95.77-4.28 \mathrm{X}_{1}-1.06 \mathrm{X}_{2}$ $0.76 \mathrm{X}_{12}-2.40 \mathrm{X}_{1}^{2}$

Disintegration Time $\left(\mathrm{Y}_{2}\right)=+36.62+16.74 \mathrm{X}_{1}+4.36 \mathrm{X}_{2}+11.54 \mathrm{X}_{1}{ }^{2}$

Tensile Strength $\left(\mathrm{Y}_{3}\right)=+1.52+0.62 \mathrm{X}_{1}+0.097 \mathrm{X}_{2}$

\section{$\%$ Cumulative drug release (\%CDR) $\left(\mathrm{Y}_{1}\right)$}

Both the independent variables $\mathrm{X}_{1}$ and $\mathrm{X}_{2}$, had a negative effect on $\%$ CDR. As the concentration of $X_{1}$ and $X_{2}$ increases from- 1 to +1 , $\%$ CDR was found to be decreasing. This can be clearly seen in the contour plot as shown in fig. 5. In general, it was found that the presence of hydrophilic additive (PEG 400) in HPMC E5 resulted in a rise in the release rate of the drug.

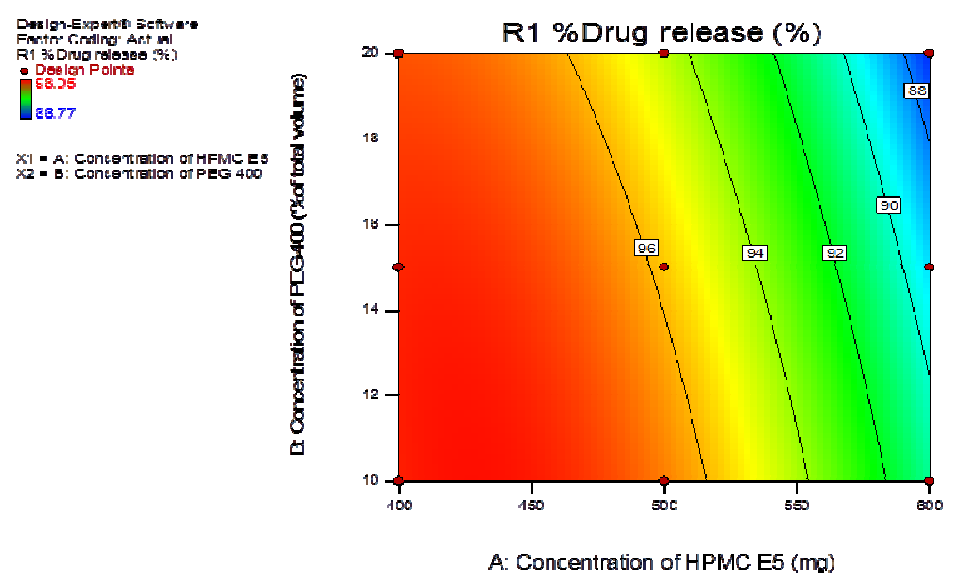

Fig. 5: Contour plot of $\% C D R$

\section{Disintegration time $\left(\mathrm{Y}_{2}\right)$}

Disintegration time was found to be increasing with the increasing concentration of $X_{1}$ and $X_{2}$ as shown in the contour plot (fig. 6). Thus the lower concentration of both the variables are preferred to obtain the fast disintegration of film. The delay in the disintegration time may be the result of increased tensile strength.

\section{Tensile strength $\left(\mathrm{Y}_{3}\right)$}

The mechanical properties of cast films were examined by tensile testing. Linear model was suggested showing that tensile strength increased with the increased concentration of PEG 400 and HPMC
E5 as seen from the contour plot (fig. 7). No interaction effect or second-order interaction affected the mechanical strength of the casted films. This might be due to the penetration of PEG chains into HPMC E5, leading to crosslinking and an increase in mechanical strength.

\section{Evaluation parameter}

\section{Weight variation}

The weight variation for all the formulation is tabulated in table 4 . It was found to be in the range of $46.21 \pm 0.1$ to $70.28 \pm 0.5 \mathrm{mg}$. The weight of all the films was found to be uniform. 

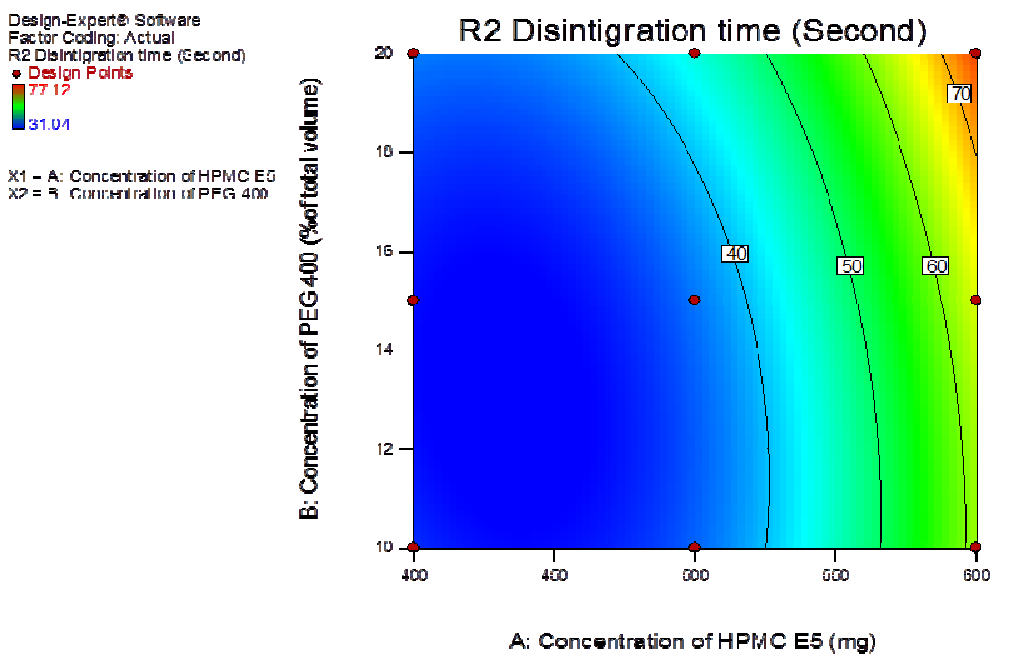

Fig. 6: Contour plot of disintegration time
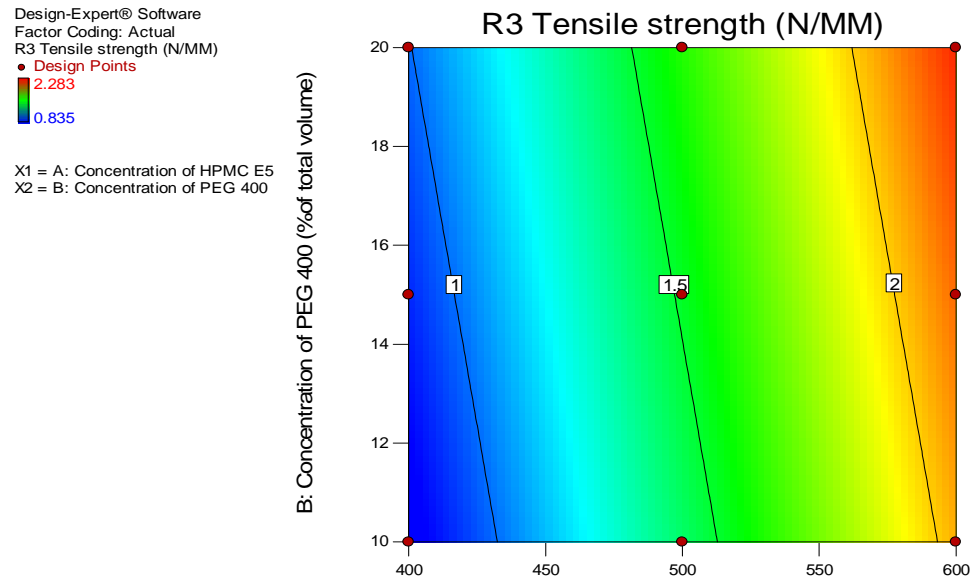

A: Concentration of HPMC E5 (mg)

Fig. 7: Contour plot of tensile strength

\section{Thickness}

The thickness of the formulated films was found to be in the range of $0.204 \pm 0.003$ to $0.195 \pm 0.002 \mathrm{~mm}$. The mean values are tabulated in table 4 . The values indicate that as the concentration of polymer increases, the thickness was found to be gradually increasing. The values are almost uniform in all formulations.

\section{Folding endurance}

The folding endurance of formulated films was found to be in range of $95 \pm 4.24$ to $221 \pm 16.26$. The mean values are tabulated in table 4 . The values indicated that as the concentration of polymer and plasticizer increases, folding endurance was found to be increasing.

\section{Drug content}

The drug content was determined to make sure uniform and accurate distribution of the drug. The drug content was performed for all the nine formulations and results are tabulated in table 4 . Three trials from each formulation were analyzed spectrophotometrically. The mean value and standard deviation of all the formulations were calculated. The results specified that in all the formulations, the drug content was uniform. The percentage drug released by each film to the in vitro release studies was based on the mean content of the drug present in the respective film. The ranges of drug content in all the formulations were $94.63 \pm 1.2 \%$ to $99.02 \pm 0.35 \%$.

Table 4: Evaluation of design batches of mouth dissolving films

\begin{tabular}{|c|c|c|c|c|}
\hline Batch & Weight variation (mg) & Thickness (mm) & Folding endurance & Drug content (\%) \\
\hline F1 & $46.21 \pm 0.1$ & $0.204 \pm 0.003$ & $95 \pm 4.24$ & $99.02 \pm 0.35$ \\
\hline $\mathrm{F} 2$ & $47.98 \pm 0.3$ & $0.202 \pm 0.003$ & $102 \pm 3.53$ & $98.52 \pm 0.70$ \\
\hline F3 & $48.30 \pm 0.1$ & $0.201 \pm 0.004$ & $115 \pm 1.41$ & $97.02 \pm 0.28$ \\
\hline F4 & $58.02 \pm 0.0$ & $0.198 \pm 0.002$ & $162 \pm 9.89$ & $97.38 \pm 1.0$ \\
\hline F5 & $58.56 \pm 0.2$ & $0.203 \pm 0.002$ & $178 \pm 12.02$ & $96.98 \pm 0.50$ \\
\hline F6 & $58.98 \pm 0.1$ & $0.196 \pm 0.004$ & $192 \pm 7.77$ & $96.57 \pm 0.12$ \\
\hline F7 & $68.67 \pm 0.3$ & $0.205 \pm 0.004$ & $199 \pm 2.82$ & $95.68 \pm 1.2$ \\
\hline F8 & $69.33 \pm 0.4$ & $0.197 \pm 0.003$ & $211 \pm 6.36$ & $93.73 \pm 0.86$ \\
\hline F9 & $70.28 \pm 0.5$ & $0.195 \pm 0.002$ & $221 \pm 16.26$ & $94.63 \pm 1.2$ \\
\hline
\end{tabular}




\section{Optimized formulation}

The optimized formula was selected based on criteria of maximum $\%$ drug release, minimum disintegration time and maximum tensile Strength. The overlay plot (fig. 8) was constructed to obtain optimized batch by using Design-Expert version 10. Optimized batch containing HPMC E5 (494.5 mg) and PEG 400 (13.6 mg) was prepared experimentally using the same procedure and same ingredients, which were utilized in the formulation of $3^{2}$ full factorial designs. The result of \% CDR, disintegration time and tensile strength was compared with that of computed values from the regression equations. When both (experimentally obtained and theoretically computed) values were compared, \% error was found to be less than $<5 \%$ for all responses. This endorsed utility of established contour plots and polynomial equations for all responses. Results of the optimized batch is shown in table 5 .

Table 5: Optimized batch evaluation

\begin{tabular}{ll}
\hline Responses & Experimental value \\
\hline \% CDR (\%) & $94.00 \pm 0.85$ \\
Disintegration time $(\mathrm{Sec})$ & $33.22 \pm 0.75$ \\
Tensile strength $\left(\mathrm{g} / \mathrm{mm}^{2}\right)$ & $1.359 \pm 0.005$ \\
Thickness $(\mathrm{mm})$ & $0.209 \pm 0.009$ \\
Drug content $(\%)$ & $97.02 \pm 0.742$ \\
Folding Endurance & $81 \pm 5.68$ \\
Disintegration time $(\mathrm{sec})$ & $33.22 \pm 0.75$ \\
\hline
\end{tabular}

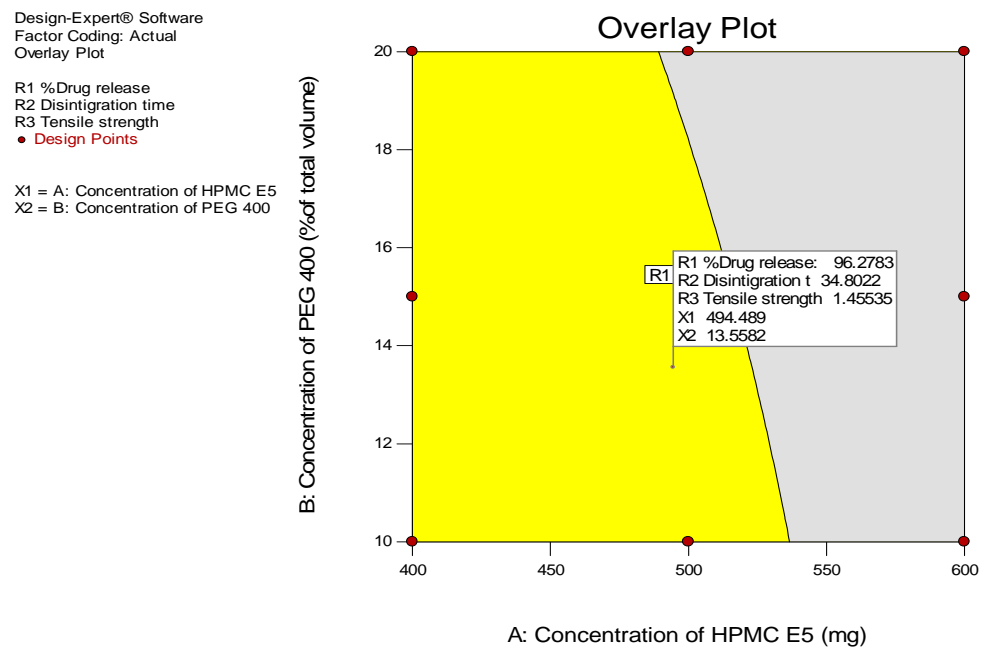

Fig. 8: Overlay plot for checkpoint batch analysis

\section{Stability studies}

The accelerated stability studies were carried for the optimized batch as per ICH guidelines. The optimized formulation was evaluated for accelerated stability studies at $40 \pm 2{ }^{\circ} \mathrm{C} / 75 \pm 5 \% \mathrm{RH}$ conditions for $1 \mathrm{mo}$ using a stability chamber. The results of stability studies are shown in table 6. At the end of studies, the sample was analyzed for drug content, disintegration time, tensile strength and folding endurance. Dissolution profile was found to be almost the same in both cases. The data, after the stability period of evaluation parameters were found nearly same as it was before the stability period. Hence stability study indicated that the formulation was quite stable at accelerated conditions. Thus, it can be concluded that the formulation is thermally stable as well as not affected by high humidity conditions.

Table 6: Result of accelerated stability studies

\begin{tabular}{lll}
\hline Evaluation parameter & Initial & After 1 mo \\
\hline Drug content $(\%)$ & $97.02 \pm 0.742$ & $95.83 \pm 0.98$ \\
$\%$ CDR $(\%)$ & $94.00 \pm 0.60$ & $92.76 \pm 0.80$ \\
Disintegration time $(\mathrm{sec})$ & $33.22 \pm 0.75$ & $39.27 \pm 0.4$ \\
Tensile strength $\left(\mathrm{g} / \mathrm{mm}^{2}\right)$ & $1.359 \pm 0.005$ & $1.139 \pm 0.033$ \\
Folding endurance & $81 \pm 5.68$ & $75 \pm 0.65$ \\
\hline
\end{tabular}

\section{CONCLUSION}

In conclusion, the developed MDF was having enhanced dissolution and acceptable taste masking by the use of a combination of HPMC E5 and PEG 400 in the concentration of $5 \% \mathrm{w} / \mathrm{v}$ and $15 \% \mathrm{w} / \mathrm{v}$ respectively. Improved dissolution of the drug may be attributed to the presence of hydrophilic polymer PEG 400. Sufficient taste masking was confirmed by using the e-tongue sensor. The Ramosetron Hydrochloride film possesses adequate mechanical strength and desired rapid disintegration leading to rapid therapeutic action and can be used as an alternate to the commercially available immediate-release tablets for controlling emesis, resulting in improved patient adherence.

\section{FUNDING}

Nil

\section{AUTHORS CONTRIBUTIONS}

All the authors have contributed equally. 


\section{CONFLICT OF INTERESTS}

The authors declare that there is no Conflict of Interest regarding the publication of this paper.

\section{REFERENCES}

1. Joshua JM, Hari R, Jyothish FK, Surendran SA. Fast dissolving oral thin films: an effective dosage form for quick releases. Int J Pharm Sci Rev Res 2016;38:282-9.

2. Gupta P, Bisht A, Rao NGR. Fast dissolving oral films: a comprehensive review. World J Pharm Res 2019;5:116-27.

3. Zarana M, Darshil B, Dilip. Development and validation of stability indicating HPLC method for estimation of ramosetron Hcl. World J Pharm Res 2014;3:4527-35.

4. Mujoo S, Ali Z, Jehangir M, Iqbal A, Qayoom N, Lone A. A comparative evaluation of ramosetron with ondansetron for the prevention of postoperative nausea and vomiting in patients undergoing urological procedures. Anesth Essays Res 2017;11:78.

5. Sarkar S, Bhattacharyya N, Palakurthi VK. Taste recognizer by multi-sensor electronic tongue: a case study with tea quality classification. In: Proceedings-2nd International Conference on Emerging Applications of Information Technology, EAIT; 2011. p. 138-41.

6. Sarkar S. Basic and mixed taste analysis using voltammetric electronic tongue. Int Conf VLSI, Commun Instrum (Icvci); 2011. p. 27-33.

7. Dangre PV, Phad RD, Surana SJ, Chalikwar SS. Quality by design (QbD) assisted fabrication of fast dissolving buccal film for clonidine hydrochloride: exploring the quality attributes. Adv Polym Technol 2019:1-13. https://doi.org/10.1155/2019/ 3682402.

8. Roshan B, Ravindranath S. Journal of drug delivery and therapeutics (jddt). J Drug Delivery Ther 2019;9:661-8.

9. Lakshmi PK, Malavika P, Vidya K. Formulation and evaluation of oral films of atomoxetine hydrochloride. Int Res J Pharm 2018;9:105-9.

10. Reddy U, Reddy S, Katta M, Thyagaraju K. A detailed review on fast dissolving oral films. Indo Am J Pharm Res 2018;8:135126. 